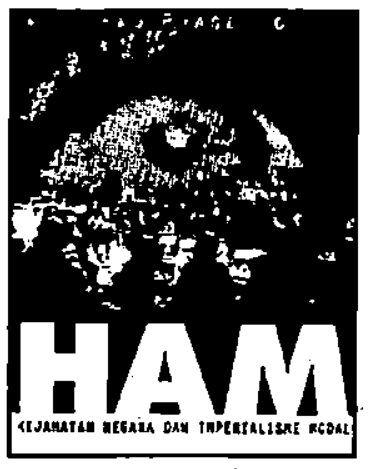

Judul Buku : HAM Kejahatan Negara dan Imperialisme Modal.

Penulis : Eko Prasetyo.

Pengantar : Dr. Mansour Fakih.

Penerbit : INSIST Press dan Pustaka Pelajar, Yogyakarta.

Cetakan I : Agustus 2001.

Tebal : $251+$ lix halaman.

\title{
Mengurai Konflik Kepentingan Modal dan Negara dengan Isu Hak Asasi Manusia
}

\author{
Mulyadi J. Amalik
}

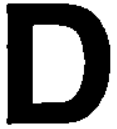

i Indonesia, isu Hak Asasi Manusia (HAM) dianggap sebagai isu yang baru. Bahkan di kalangan umat Islam, isu HAM selalu dianggap berbau kepentingan Barat. Karena anggapan itu, maka banyak muslim Indonesia yang meyakini HAM sebagai isu yang tabu. Lalu, muncul sikap antipati atau prasangka yang berlebihan terhadap orang lain yang berbicara kemanusiaan atas nama HAM.

Sikap umat Islam itu sebangun pula dengan sikap pemerintah Indonesia, terutama karena isu (pelanggaran) HAM itu sering diungkit oleh aktivis atau pemerintah negara asing. Siapa pun yang melontarkan isu pelanggaran HAM pada masa Orde Baru, misalnya, pasti akan berhadapan dengan negara atau aparatur birokrasinya. Apalagi, bila isu pelanggaran HAM itu dilontarkan oleh aktivis prodemokrasi dari dalam negeri sendiri, maka militer-lah yang akan menghadangnya dengan delik subversi.

Dari situasi di atas, lalu muncul sebuah pertanyaan yaitu "Saat kapan pemerintah Indonesia mau peduli dengan isu HAM?" Pada tahun 1980-an atau 1990-an, pertanyaan ini hanya bisa dijawab melalui perubahan besar-besaran di sektor elit politik atau elit penguasa termasuk militer. Akan tetapi, ketika perubahan politik dan kekuasaan di Indonesia itu terjadi pada 
tahun 2000-an setelah digoyang gerakan Reformasi 1998, pertanyaannya belum juga terjawab. Tentulah karena ada beberapa persoalan yang menjadi penyebabnya. Buku HAM, Kejahatan Negara dan Imperialisme Modal yang ditulis oleh Eko Prasetyo ini sudah menjawab berbagai faktor penyebab mengapa isu HAM di Indonesia tidak populer. Faktor penyebab tersebut dapat dirangkum dalam beberapa poin seperti berikut:

Faktor kesatu, yaitu tentang perdebatan sejarah lahirnya HAM. Banyak kalangan mengatakan bahwa ide HAM muncul dari konflik dan pasang surut kekuasaan kaum feodal di Eropa Barat dan Amerika Utara (halaman 8-12). Di Inggris pada tahun 1215, misalnya, resolusi atas konflik itu melahirkan kesepakatan yang dituangkan dalam Magna Charta Libertatun yang isinya melarang penahanan, penghukuman, dan perampasan benda-benda hak milik secara sewenang-wenang oleh penguasa. Lalu pada tahun 1679, muncul pula dokumen hukum yang dinamai Habeas Corpus yang memberikan dasar legitimasi pada kekuasaan kehakiman. Sepuluh tahun kemudian, lahirlah istilah "rights" (hak-hak) mengikuti berlakunya undang-undang hak bagi masyarakat Inggris yang dikenal dengan Bill of Rights.

Sementara sebelumnya, di Amerika telah muncul pemikiran tentang toleransi yang dituangkan oleh John Locke dalam buku Second Treatise of The Government. Dalam pemikirannya itu Locke sangat banyak mengemukakan nilai-nilai religius dan etika perspektif Bibel. Namun begitu, banyak pihak tetap meragukan sumbangan pemikiran Locke tersebut terhadap ide HAM karena terbukti bahwa ada banyak gereja yang telah bersekutu dengan kaum modal dan rezim atau penguasa yang diktator/dzalim.
Sebagian pengamat HAM yang berbasis filsafat menganggap bahwa monumen terkuat lahirnya HAM dimulai dari Revolusi Perancis tahun 1789. Revolusi sosial dan politik di Perancis ini memang mengusung sejumlah gagasan filosofis dari JeanJacques Rousseau tentang kebebasan (liberte), kesamaan (egalite), dan kesetiakawanan (fraternite). Atas dasar ini, lalu lahirlah hak-hak manusia dan warga negara. Akan tetapi, kaum ilmuwan kiri menganggap Revolusi Perancis tahun 1789 itu sebagai revolusi kaum borjuis yang dilatari oleh konflik kepentingan individu para bangsawan pemilik modal dengan para bangsawan yang berkuasa. Bahkan Karl Marx berpendapat bahwa deklarasi hak asasi manusia di Perancis pada tahun 1789 hanya menyerukan hak asasi individu yang bersifat mengisolasi diri dan menyendiri. Dalam kata lain, hak atas kebebasan tidak didasarkan pada komunitas antarmanusia (kolektifitas), melainkan pemisahan seorang manusia dari manusia yang lain.

Sementara kritik dari kelompok sayap kanan penganut Hegelian, mengatakan bahwa HAM yang lahir dari Revolusi Perancis adalah perwujudan dari ideologi borjuis yang menghancurkan solidaritas kemanusiaan. Menurut kelompok ini, HAM pun tidak tumbuh dari semangat atau tradisi keagamaan di Eropa karena pasca-Revolusi Perancis terdapat beberapa gereja yang menentang HAM. Penentangan pihak gereja terhadap isu HAM itu dilatari oleh rasa takut dan kuatir mereka pada radikalisme antikependetaan dalam fase Jakobin. Dalam contoh lain diterangkan pula bahwa Paus Pius XI berada dalam posisi terdepan dalam mengutuk gerakan yang menganut kebebasan religius dan kebebasan pers. Akan tetapi, ada juga kalangan kritikus ini yang mengatakan bahwa pada tahun 1960-an atau akhir abad ke-19 pihak gereja telah mendukung 
konsep HAM yang ditandai oleh lahirnya Konsili Vatikan II.

Melalui buku HAM, Kejahatan Negara dan Imperialisme Modal ini (halaman 13) si penulis -sambil mengutip beberapa pendapat- ingin mengatakan bahwa ide HAM tidak lahir dari pergulatan organik dari sejarah dan budaya oksidental (ketimuran), melainkan capaian yang diperoleh dari konflik politik yang berlangsung lama bersamaan dengan proses modernisasi di Eropa. Jadi, hak-hak itu bukanlah warisan abadi dari kebudayaan asli Eropa. Lantas, bila ada yang mengatakan bahwa asal-mula HAM itu dari Barat, maka rujukannya hanya pada fakta tentang ide HAM universal (seperti soal kemerdekaan dan kesetaraan) sejauh hal itu diketahui dari pengalaman orang di Eropa Barat dan Amerika Utara.

Dengan demikian, sejarah HAM di Barat bukanlah satu-satunya model yang wajib dipakai untuk memformat persoalan HAM dan resolusi konfliknya untuk masa depan. Akan tetapi, persoalan ini tidak pernah selesai diperdebatkan karena perbedaan titik pijak sejarah dan paradigma hingga muncul dua cara pandang HAM yang sering diperlawankan yaitu universalime HAM versus partikularisme HAM. Umat Islam dan juga pemerintah Indonesia lebih memilih partikularisme HAM untuk menyatakan penolakannya terhadap "HAM yang bias Barat". Masalahnya, penolakan umat Islam dan juga pemerintah Indonesia itu kadang hanya ditampilkan dalam rangka menegasikan "HAM yang bias Barat" dan tidak disertai oleh semangat merumuskan model instrumen HAM menurut versi yang diyakininya sendiri.

Faktor kedua, yaitu tentang batasbatas atau persinggungan antara hukum dan HAM: Pada buku HAM, Kejahatan Negara dan Imperialisme Modal ini penulisnya memang tidak membahas secara khusus dan eksplisit mengenai batas-batas atau persinggungan hukum dan HAM. Namun begitu, pada bagian pengantar buku di bawah judul Lawan Rezim Fasis!! Sebuah Pengantar (halaman xvii-xlviii) yang disusun oleh Tim insist Press tergambar sejumlah pandangan tentang filsafat hukum dan konflik kepentingan dalam praktek hukum serta persinggungannya dengan HAM.

Ada dua pandangan substansial yang saling berhadapan dan sering muncul dalam perdebatan tentang batas dan persinggungan hukum dengan HAM. Pandangan pertama ialah pandangan normatif yang mengatakan bahwa HAM adalah bagian dari hukum. Kelompok ini beranggapan bahwa segala persoalan HAM justru diatur oleh hukum, dan bukan sebaliknya. Kelemahan kelompok ini tentu saja terletak pada cara pandangnya terhadap hukum. Pada kasus Indonesia, hukum dianggap berada di atas segalanya. Oleh karena itu, Indonesia mengklaim diri sebagai negara hukum. Misalnya, terlihat pada tata peraturan perundang-undangan Indonesia yang disebut sebagai sumber hukum yaitu Pancasila, UUD 1945 , Ketetapan MPR (TAP MPR), Keputusan Presiden (Kepres), Peraturan Pemerintah (PP), dan Peraturan Pemerintah Pengganti Undang-undang (Perpu), dan seterusnya. Akan tetapi, dalam prakteknya justru terjadi unifikasi hukum. Pada awalnya, unifikasi hukum ini dilakukan oleh pemerintah Indonesia dalam rangka keluar dari kepungan kekuasaan kolonial Belanda yang menciptakan hukum secara beragam. Unifikasi hukum juga dilakukan untuk memperkuat citra dan identitas nasional bangsa Indonesia. Namun, faktanya adalah sentralisasi kekuasaan yang mutlak di tangan pemerintah pusat (negara). Oleh karena itu, dapat dipastikan bahwa seluruh pelanggaran HAM di Indonesia pada masa 
Orde Baru selalu dilakukan oleh aparatur negara. Di dalam buku HAM, Kejahatan Negara dan Imperialisme Modal ini Eko menjelaskan banyak hal tentang kejahatan negara melalui bagan dan tabel (halaman $80,83-86,90,95,98-101,131,137,165$, dan 235-241). Produk hukum dan cara kerja militer Indonesia paling banyak mendapat perhatian oleh penulis buku ini karena selalu menjadi sebab atau pelaku utama pelanggaran HAM.

Pandangan kedua ialah pandangan substansialistik yang mengatakan bahwa HAM lebih luas dari hukum. Dalam kata lain, kelompok ini menganggap hukum sebagai alat resolusi konflik HAM. Kelemahan kelompok ini terletak pada cara atau praktek penegakan HAM di tengah masyarakat karena ada banyak persoalan HAM (seperti di Indonesia) yang tidak tertuang dalam perangkat hukum. Persoalan berikutnya terletak pada political will negara atau penguasa dalam hal pembentukan sebuah undang-undang, peraturan, atau hukum. Padahal, dalam konteks Indonesia, semua orang sudah tahu bahwa tidak ada rezim yang betul-betul bersih dari nepotisme, korupsi, dan kolusi. Dengan demikian, tidak akan ada pula kebijakan negara yang menyangkut hak-hak rakyat yang diberikan secara gratis oleh penguasa. Akan tetapi, kelompok yang menganut pandangan ini memiliki paradigma struktural yang kuat tentang konflik kepentingan HAM sehingga pelaku dan korban pelanggaran HAM selalu dihadapkan secara tegas. Biasanya, menurut kelompok penganut pandangan substansialistik ini, negara selalu berada diposisi sebagai pelaku utama pelanggaran HAM terhadap rakyat. Oleh karena itu, perangkat hukum yang dibentuk oleh penguasa negara selalu berisi proteksi untuk penguasa sendiri, sedang rakyat akan dikorbankan. Seperti ditulis Eko dalam bukunya ini, Indonesia adalah negara yang memiliki kenyataan seperti itu. Dalam kata lain, Indonesia adalah negara yang giat meratifikasi berbagai konvensi internasional tentang HAM, tetapi paling giat pula melakukan pelanggaran HAM. ${ }^{1}$

'Pada tahun 1958, dengan UU No. 68, pemerintah Indonesia meratifikasi Konvensi Hak Politik Perempuan yang diadopsi oleh PBB dalam tahun 1952. Kemudian, melalui UU No. 7/1984, pemerintah Indonesia meratifikasi Konvensi Penghapusan Segala Bentuk Diskriminasi terhadap Perempuan yang diadopsi PBB dalam tahun 1979. Melalui Keputusan Presiden R.I. No. 36/1990, Indonesia juga meratifikasi Konvensi Hak Anak yang diadopsi Majelis Umum PBB pada 20 November 1989. Setelah gerakan prodemokrasi berhasil menjatuhkan rezim Jenderal (Purn.) Soeharto, pemerintah Indonesia menuai kritik yang pedas dari kalangan aktivis dalam negeri maupun luar negeri karena terkuaknya berbagai pelanggaran HAM yang dilakukan oleh negara (dan terutama militer). Oleh karena itu, melalui UU No. 5/1998, pemerintah Indonesia masa Presiden B.J. Habibie meratifikasi Konvensi Antipenyiksaan dan Perlakuan Penghukuman Lain yang Kejam, Tidak Manusiawi, atau Merendahkan Martabat. Manusia. Masih dalam tahun 1998, pemerintah Indonesia meratifikasi pula Konverisi ILO No. 87 tentang Kebebasan Berserikat dan Perlindungan Hak Berorganisasi. Pada tahun 1999, pemerintah Indonesia meratifikasi Konvensi Penghapusan Segala Bentuk Diskriminasi Rasial melalui UU No. 29/1999. Akan tetapi, semangat meratifikasi berbagai konvensi ini belum berbanding lurus dengan semangat pemerintah dalam penegakan HAM karena budaya politik para pejabat pelaku pelanggaran HAM pada masa Orde Baru masih sangat primitif (Tim Komnas HAM, 2000, Pendidikan Hak Asasi Manusia: Panduan untuk Fasilitator, Yogyakarta: Komnas HAM dan INSIST, halaman 86-87). 
Memang, "pemerintah Indonesia telah membentuk UU No. 39/1999 tentang HAM dan UU No. 26/2000 tentang Peradilan HAM. Namun, menurut Eko (halaman 197199), prosedur yang ditetapkan dalam UU No. 26/2000 tentang Peradilan HAM ternyata sangat bertele-tele dan syarat dengan muatan politis. Ada simpang-siur wewenang dan tangggung jawab antara Komnas HAM, Jaksa Agung, DPR, Presiden, dan Pengadilan HAM Ad Hoc. Dalam pasal 18 UU No. 26/2000 dinyatakan bahwa penyelidikan pelanggaran HAM berat dilakukan oleh Komnas HAM dan bila ditemukan bukti awal yang mencukupi, maka kesimpulannya akan disampaikan pada penyidik. Pada pasal 21 UU yang sama dijelaskan bahwa pihak penyidik itu ialah Jaksa Agung. Berkas penyidikan dari tangan Jaksa Agung inilah yang akan diserahkan kepada Dewan Perwakilan Rakyat (DPR) sebagai penjelasan bahwa memang ada dugaan kuat telah terjadi pelanggaran HAM berat. Berdasarkan dugaan kuat itu, seharusnya DPR mendesak Presiden agar secepatnya membentuk pengadilan HAM ad hoc. Akan tetapi, ternyata DPR membentuk panitia khusus (pansus) melalui sebuah voting yang hasilnya adalah menolak rekomendasi pengadilan HAM ad hoc. Peristiwa ini terjadi di DPR saat penentuan kasus pelanggaran HAM berat oleh aparat Polisi/ TNI terhadap aksi mahasiswa di Trisakti, Semanggi I, dan Semanggi II di Jakarta.

Jadi, tampaklah bahwa negara atau penguasa (legislatif, yudikatif, dan eksekutif) masih menjadi faktor penghalang terkuat bagi penegakan HAM di Indonesia. Padahal, dalam Deklarasi Wina (1993) dikatakan bahwa pihak pertama yang berkewajiban menegakkan HAM adalah negara dan karena itu setiap pemerintahan di negara mana pun dianjurkan meng-abungkan standar-standar yang terdapat dalam instrumen-instrumen HAM ke dalam hukum nasionalnya. Dalam Deklarasi Wina (1993) ini pula definisi HAM diperkuat lagi hingga menjadi prinsisp kesatupaduan: "semua hak asasi manusia itu adalah bersifat universal, tidak dapat dibagi-bagi dan saling berkaitan antarsesamanya." Dengan demikian, hakhak manusia yang bersifat sipil, budaya, ekonomi, politik, dan sosial harus dilihat secara keseluruhan dengan makna dan nilai yang sama penting. ${ }^{2}$

Faktor ketiga, yaitu konflik HAM yang seiring dengan konflik kepentingan modal. Faktor ketiga ini akan sangat akrab dengan isu gerakan neoliberalisme yang saat ini sedang gencàr dikritik oleh kelompok antiglobalisási. Peta kekuatan politik internasional dan nasional - terutama di negara-negara Dunia Ketiga - pun akhirnya terbagi secara jelas dalam dua kutub besar yang kongkret yaitu kelompok antimodal versus kelompok pendukung mọdal.

Dalam Kata Pengantar buku HAM, Kejahatan Negara dan Imperialisme Modal ini (halaman iv-v), Mansour Fakih menyatakan bahwa bila ditinjau dari sudüt ekonomi dan budaya, maka pelanggaran HAM di Indonesia telah terjadi sejak era Kolonialisme hingga pascakolonialisme yaitu era Developmentalism (Pembangunanisme). Pembangunan(isme) yang dilakukan oleh pemerintah Indonesia dalam rangka mengejar pertumbuhan ekonomi pada era pascakolonial, ternyata menjadi akar pelanggaran HAM yang berlapis-lapis. Dalam kata lain, berbagai program pembangunan(isme) yang lakukan oleh negara telah menimbulkan berbagai patologi sosial berdimensi HAM yaitu kejahatan terhadap kemanusiaan.

2/bid., halaman 84-85. 
Menurut Mansour Fakih, ${ }^{3}$ jika fase kolonialisme disebut sebagai fase awal dari sebuah model penjajahan karena bersifat fisik, maka fase developmentalism disebut sebagai fase neo-kolonialisme (fase penjajahan model kedua) yang lebih bersifat hegemoni teori dan ideologi. Dalam konteks kedua jenis fase penjajahan ini, hubungan negara kaya dengan negara miskin tetap bersifat paternal (negara kaya menggantung negara miskin), tetapi alat eksploitasinya tidak lagi sama. Pada fase penjajahan model awal, alat eksploitasinya berupa kekuatan bersenjata atau kekuatan perangkat perang. Sedangkan pada fase penjajahan model developmentalism, alat eskploitasinya berupa hegemoni atau sentralisasi kekuatan ilmu-pengetahuan dan teknologi (IPTEK). Ketika kedua fase penjajahan ini mengalami krisis, persekutuan negara kaya telah menyiapkan satu mode of domination yang sekarang populer disebut sebagai fase globalisasi. Fase globalisasi ini muncul menjelang abad ke-21 dan merupakan model penjajahan tahap ketiga yang ditandai oleh proses liberalisasi segala bidang melalui structural adjustment program dari lembaga finansial global, dan disepakati oleh rezim General Agreement on Tariff and Trade (GATT) dan rezim Perdagangan Bebas yang dikenal dengan nama World Trade Organization (WTO).

Istilah "globalisasi" dapat dipahami sebagai proses pengintegrasian ekonomi nasional bangsa-bangsa ke dalam suatu sistem ekonomi global. Berdasarkan sejarah ekonomi, globalisasi merupakan salah satu fase dari perjalanan panjang pergerakan kapitalisme liberal yang secara teoretis telah dikembangkan oleh Adam Smith. Jadi, tidak ada perubahan ideologi dari ketiga fase penjajahan (kolonialisme, developmentalism/pembangunanisme, dan globalisasi) di atas karena secara ekonomis tetap berwatak eksploitatif, secara politis berwatak represif, dan secara kultural berwatak hegemonik dan diskursif. Pelakunya tentulah sebagian elit masyarakat yang dominan, sedangkan korbannya adalah rakyat kecil yang lemah dalam sektor ekonomi, politik, dan budaya. Namun demikian, ada juga perbedaan terpenting antara fase pembangunanisme dan fase globalisasi. Jika fase pembangunanisme bertumpu pada target pertumbuhan ekonomi nasional dan lebih melihat ke dalam negeri sendiri, maka fase globalisasi bertumpu pada kekuatan (atau menjadi bagian) dari pertumbuhan ekonomi global. Pada fase globalisasi ini, negara tidak lagi menjadi aktor tunggal atau pelaku utama karena telah memperoleh rekanan yaitu perusahaan-perusahaan transnasional (Transnational Corporations/TNCs), bankbank transnasional (Transnational Banks/ TNBs), dan lembaga keuangan multilateral seperti World Bank (Bank Dunia), International Monetery Fund (IMF), serta birokrasi perdagangan regional maupun global seperti World Trade Organization (WTO), The North American Free Trade Agreement (NAFTA), The Asia Pasific Economic Conference (APEC), atau Association South East Asian Nations (ASEAN). ${ }^{4}$

Dalam fase globalisasi inilah konflik kepentingan modal saling bertarung antarbangsa dan lalu mengerucut di tingkat

${ }^{3}$ Mansour Fakih, Sesat Pikir Teori Pembangunan dan Globalisasi, Yogyakarta: Pustaka Pelajar dan INSIST Press, 2001, halaman 208-210.

${ }^{4} / \mathrm{bid}$., halaman $210-211$. Tentang isu HAM yang sering digunakan oleh Bank Dunia dan IMF untuk menekan negara-negara yang diutanginya, dapat dilihat dalam buku Daniel D. Bradlow, Bank Dunia, IMF dan Hak Asasi Manusia, Jakarta: ELSAM, 1999. 
internal bangsa-bangsa menjadi konflik kepentingan antara negara dan rakyat dalam satu bangsa. Oleh karena itu, jika tampilan sebuah negara sangat kuat, maka bisa jadi tampilan rakyatnya sangat lemah. Pada situasi inilah pelanggaran HAM oleh negara terhadap rakyatnya pasti tak terelakkan. Secara kongkret, kunci konflik' kepentingan antara negara dan rakyat yang selalu berdimensi pelanggaran HAM ini terletak pada politik-utang luar negeri (oleh negara-negara kaya untuk negara-negara miskin), yang dikamuflase oleh pemerintah Indonesia pada masa Orde Baru dengan istilah "bantuan luar negeri".

Menurut Joseph Hanlon, ${ }^{5}$ seperlima dari semua utang (oleh negara-negara kaya, mja) kepada negara berkembang merupakan pinjaman yang mendukung munculnya para diktator. Mobutu, Marcos, Soeharto, dan para penguasa kejam lainnya merupakan orang-orang yang didukung dengan pinjaman (utang) yang besar. Meskipun orang-orang ini melakukan pelanggaran HAM yang berat, melakukan korupsi besar-besaran, dan secara terangterangan mentransfer uangnya ke bankbank Swiss, tetap saja mereka mendapatkan utangan dari negara pengutang. Lalu, bagaimana jika para penguasa ini jatuh dari tampuk kekuasaannya?? Tentulah penggantinya yang akan membayar atau menanggung utang-utang tersebut. Sementara itu, rakyat dan generasi muda akan menjadi korban yang paling menderita di lapis berikutnya, walaupun mereka tidak pernah setuju atau tidak pernah mendapat bagian dari utang-utang itu sebab telah dimakan lebih dulu oleh para koruptor di birokrasi negara.

Dalam buku HAM, Kejahatan Negara dan Imperialisme Modal ini, Eko - sembari mengutip tabel data Transparency International (www.gwdg.de) dari Tempo, 11 Februari 2001- menunjukan skor angka dan peringkat korupsi Indonesia dibanding negara-negara sejenis (halaman 90):

\begin{tabular}{|c|c|c|c|c|c|}
\hline 1995 & 1996 & 1997 & 1998 & 1999 & 2000 \\
\hline $\begin{array}{l}1,94 \\
\text { (terkorup } \\
\text { di dunia dari } \\
41 \text { negara) }\end{array}$ & $\begin{array}{l}2,65 \\
\text { (terkorup } \\
\text { ke-10 dari } 54 \\
\text { negara) }\end{array}$ & $\begin{array}{l}2,72 \\
\text { (terkorup } \\
\text { ke-7 dari } 52 \\
\text { negara } \\
\text { setelah } \\
\text { Meksiko, } \\
\text { Pakistan, } \\
\text { Rusia, } \\
\text { Bolivia, } \\
\text { Kolumbia, } \\
\text { dan Nigeria. }\end{array}$ & $\begin{array}{l}2,0 \\
\text { (terkorup } \\
\text { ke-6 dari } 85 \\
\text { negara setelah } \\
\text { Nigeria, } \\
\text { Tanzania, } \\
\text { Honduras, } \\
\text { Paraguay, dan } \\
\text { Kamerun. }\end{array}$ & $\begin{array}{l}1,7 \\
\text { (terkorup } \\
\text { ke-3 dari } 99 \\
\text { negara } \\
\text { setelah } \\
\text { Nigeria dan } \\
\text { Kemerun. }\end{array}$ & $\begin{array}{l}1,7 \\
\text { (terkorup } \\
\text { ke-5 dari } 90 \\
\text { negara } \\
\text { setelah } \\
\text { Azerbaijan, } \\
\text { Ukraina, } \\
\text { Yugoslavia, } \\
\text { dan Nigeria. }\end{array}$ \\
\hline
\end{tabular}

${ }^{5} J o s e p h$ Hanlon, Warisan Hutang Rezim Diktator, Yogyakarta: INSIST Press dan PIRAC, 2000, halaman 3-4. 
Jika muncul pertanyaan tentang bagaimana penguasa Orde Baru —dengan trilogi-prilakunya: korupsi, kolusi, dan nepotis- menggunakan utang-utangnya, maka jawabannya tentu panjang seperti berikut: a) lembaga pengutang seperti Bank Dunia sudah memvonis bahwa dana pembangunan hasil utangan untuk Indonesia selalu dikorupsi sekitar $30 \%$; b) munculnya "pengungsi pembangunan" yang sudah menjadi rahasia umum dunia internasional seperti pada kasus Kedung Ombo, Nipah, Tanjung Priok, WarsidiLampung, Daerah Operasi Militer (DOM) - Tim-Tim, DOM Aceh, dan seterusnya; dan c) terjadi kerusakan lingkungan atau pengrusakan hutan dan sumberdaya alam lainnya oleh kaum pemodal yang bersekutu dengan negara karena kesalahan kebijakan (bukan karena bencana alam). ${ }^{6}$ Lalu, apa masalahnya di sini? Inilah pokok soalnya: pihak pemberi utang dan pengutang setali tiga uang dalam hal penumpukan harta kekayaan dan penghisapan atas manusia lain untuk kepentingan pribadi. Dalam kata lain, keduanya adalah penjajah tanpa panji-panji perang yang disebut oleh Kitab Suci sebagai musuh ghaib yang kasat mata.

Buku ini memang tidak cukup fokus dan tidak mendalam karena ingin mengurai dua hal yang sama besar dan rumit yaitu soal kejahatan negara dan kejahatan imperialisme modal. Bila dua masalah ini dipecah, mungkin bisa menjadi dua buku yang sama pentingnya untuk saling melengkapi. Sisi lain yang menggangu ialah pada tata bahasa. Perlu diungkapkan bahwa Eko tidak cukup disiplin dalam hal ini sehingga banyak kalimat yang tidak efektif dan banyak kata yang kekurangan huruf. Bagi seorang kutu buku dan pembaca cepat, tentu pula akan kecewa karena buku ini tidak dilengkapi dengan indeks.
Akan tetapi, Eko berusaha menampilkan data-data melalui tabel yang memang cukup penting disimak seperti pada lampiran kasus di akhir buku yang memuat sejumlah kejahatan negara (pemerintah Indonesia) melalui tangan militernya. Tampaknya, buku ini lahir dari pergulatan penulisnya yang banyak bergelut di dunia gerakan mahasiswa maupun LSM. Apalagi, basis pendidikan si penulis juga berlatar hukum internasional sehingga isu HAM dan imperialisme modal dapat diurai secara sederhana (persuasif dan provokatif).

\section{Daftar Bacaan:}

Daniel D. Bradlow, 1999, Bank Dunia, IMF dan Hak Asasi Manusia, terjemahan Yanuar Sumarlan, The World Bank, The IMF, and Human Rights (Transnational Law and Contemporary Problems, Vol. I, Number I, 1996), Jakarta: ELSAM.

Joseph Hanlon, 2000, Warisan Hutang Rezim Diktator, terjemahan Zaim Zaidi dan Kurniawati, Yogyakarta: INSIST Press dan PIRAC.

Mansour Fakih, 2001, Sesat Pikir Teori Pembangunan dan Globalisasi, Yogyakarta: Pustaka Pelajar dan INSIST Press.

Tim Komnas HAM, 2000, Pendidikan Hak Asasi Manusia: Panduan untuk Fasilitator, Yogyakarta: Komnas HAM dan INSIST.

'Lihat Zaim Zaidi dalam "Pengantar" buku Joseph Hanlon, Warisan Hutang Rezim Diktator, Yogyakarta: INSIST Press dan PIRAC, 2000, halaman xi-xii. 